Aim of the study: The FJ 194940.1 gene is located on chromosome 1 and consists of 6 exons and 5 introns. The gene undergoes alternative splicing and its isoforms appear during cancer development. Evidence suggests that expression of FJ 194940.1 splice variants relate to colorectal cancer progression. This paper discusses the quantitative analysis of the exon V expression level of FJ 194940.1 in colon cancer. The aim of the study is to carry out quantitative analysis by realtime PCR in a series of 102 colon cancer samples that had previously shown presence of exon $V$ expression. To compare the exon $\vee$ expression level with certain histological parameters and clinical staging of the neoplasm in order to assess its potential role as a prognostic factor in colon cancer.

Material and methods: Tissue specimens of colorectal cancer were obtained from the Oncological Centre of Lodz, Poland.Total RNA isolation was performed in accordance with the protocol enclosed in the Total RNA Prep Plus Minicolumn Kit (A\&A Biotechnology, Poland). Reverse Transcriptase-PCR reaction was carried out using Enhanced Avian HSRT PCR Kit, Sigma, according to the manufacturer's protocol.. Presence of cDNA in each sample was checked by PCR amplification of $\beta$-actin. Only samples showing the PCR product of this housekeeping gene were included in further tests. The amount of FJ 194940.1 transcript containing exon $V$ was analysed by means of real-time PCR.

Results: Exon $V$ expression level is not significantly related to any clinicopathological features in colon cancer. However, there was a tendency towards a lower exon $\mathrm{V}$ expression level in a group of cases where vessel invasion was present ( $p=0.0697$ ). Additionally, the risk of death in patients with a low exon $V$ expression level was more than two times higher when compared to patients with a high exon $\mathrm{V}$ expression level.

Conclusions: FJ 194940.1 gene expression correlates with cancer progression independently of analysed clinicopathological parameters.

Key words: FJ 194940.1, expression, alternative splicing, transcript, colon cancer.

\section{Quantitative analysis of FJ 194940.1 gene expression in colon cancer and its association with clinicopathological parameters}

\author{
Malwina Bartczak-Tomczyk, Aleksandra Sałagacka, Marek Mirowski, \\ Agnieszka Jeleń, Ewa Balcerczak
}

Laboratory of Molecular Biology and Pharmacogenomics, Department of Pharmaceutical Biochemistry, Medical University of Lodz

\section{Introduction}

Colon cancer is a very serious clinical problem. It is the second most frequent cause of cancer mortality in the world's more developed countries. Over the past 15 years, researchers have submitted a lot of evidence to show that colorectal cancer (CRC) is a progressive genetic disease [1]. It is now clear that neoplasm development is a complex multistep process. Multiple molecular pathways exist in colorectal tumourgenesis in addition to the classic suppressor and mutator mechanisms [2]. Despite the wealth of knowledge that exists regarding the genetic background of this disease, there is still a need to look for some missing points in the development of this tumour.

The characterisation of splicing deregulation in cancer may lead to greater comprehension of malignant transformation, especially as specific alterations in splicing patterns exist in cancer-associated genes. Many of these changes may play a functional role in transformation, motion and metastasis of tumour cells [3, 4]. Alternative splicing variants of those genes may have prognostic or predictive values that could facilitate diagnostic and/or treatment procedures. Consequently, experimental research focuses on splice variants appearing during cancerogenesis, which could potentially become new molecular markers [5]. Abnormal splicing of several genes has been observed in tumours of colorectal origin, e.g. CD44 [6, 7], MUC2 [8], SRF [9], NCAM [10], $M L H, M S H$ [11] and members of the Wnt pathway [12]. There is evidence that FJ 194940.1 gene variants play an important role in colon tumourigenesis [13].

The FJ 194940.1 gene is located on chromosome 1, region 224792167 224794166. In normal human tissues, this chromosome region is expressed as the AK055856 transcript only in the kidney. Probably during cancerogenesis, integration of an additional copy of rv 001141 changes this transcription region. The new transcript has 921 bp and encodes a protein that contains an integrase core domain similar to the human protein EAW69787. Genomic DNA of the new transcript spans $3518 \mathrm{bp}$ and consists of five exons and four introns [14].

Studies have shown that the FJ 194940.1 gene may be a potential molecular marker of cancer development and progression [15-17]. Some of these indicated that the expression of elements of the FJ 194940.1 gene is associated with clinical stages of colon cancer. Expression of the whole exon V of FJ 194940.1 as well as fragments of exon IV and VI was found at advanced stages of cancer development [18]. This observation was further confirmed by quantitative analysis in the same colon cancer cases. A high expression level of this FJ 194940.1 transcript fragment was found in patients with metastases to lymph nodes and distant metastases, and in cases with vessel invasion and absence of lymphocytes 
in tumour tissue. The level of expression was associated with shorter survival time [16]. Interestingly, the expression of those elements was not regular [18].

A forward preliminary assay has taken into consideration the whole transcript of the FJ 194940.1 gene. This report stated that FJ 194940.1 undergoes alternative splicing. Exon V was irregularly observed in 30 investigated colon cancer cases but its expression was not significantly connected with any clinicopathological features [14].

Results obtained by Bartczak et al. [13] have confirmed that FJ 194940.1 undergoes alternative splicing. Expressions of exons and exon-exon junctions were not associated with any clinicopathological features in colon cancer. On the other hand, exon $\mathrm{V}$, the object of the present study, was an element of the part B transcript (comprising exon IV, $\mathrm{V}$ as well as III/IV and IV/V exon-exon junction). The presence of part B expression was connected with cases of low-grade malignancy, which correlated with better prognosis for patients [13]. Importantly, the expression of exon $V$ was found in all of the investigated samples [13].

The discrepancies described regarding the potential prognostic value of FJ 194940.1 gene expression in colon cancer, as well as the precursory character of the mentioned study, indicate the need for a more searching investigation.

The study presented here is a follow-up to the Bartczak et al. experiment [13], where in exon $V$ expression was detected in all examined samples. Additionally, this exon is a part of the FJ 194940.1 transcript fragment that was studied by Balcerczak E. et al. in 2003 [18] and Balcerczak M. et al. in 2007 [16]. The aim of this presented study was to investigate the exon V FJ 194940.1 gene expression level, quantified by real-time PCR, in a series of 102 colon cancer cases, and evaluate its utility as a prognostic marker in colon cancer patients.

\section{Material and methods}

\section{Materials}

Tissue specimens of colorectal cancer were obtained from the Oncological Centre of Lodz, Poland. CRC was diagnosed by histopathological examination using established clinical criteria (TNM classification by Jass with latest revision Cancer Staging Manual by AJCC, 1997) at the Department of Pathology, Medical University of Lodz, Poland. Tissue samples from 102 patients were frozen in liquid nitrogen immediately after surgery and stored at $-80^{\circ} \mathrm{C}$ until further examination. The characteristics of the examined population are shown in Table 1.

All experiments were carried out with local ethical committee approval (No. RNN/214/00) and patients' informed consent.

\section{RNA isolation}

Total RNA isolation was performed in accordance with the protocol enclosed in the Total RNA Prep Plus Minicolumn Kit (A\&A Biotechnology, Poland). The method is based on RNA isolation methodology developed earlier by Chomczynski and Sacchi, 1987 [20]. RNA concentration was determined spectrophotometrically. The isolated RNA had an A260/280 ratio of 1.6-1.8. Purified RNA samples were stored at $-80^{\circ} \mathrm{C}$.

Table 1. Comparison of FJ 194940.1 exon V expression level with clinicopathological parameters

\begin{tabular}{|c|c|c|c|c|c|c|c|c|}
\hline Feature & & $n$ & Median & Minimum & Maximum & Lower quartile & Upper quartile & $p$ value \\
\hline \multirow[t]{2}{*}{ Gender } & female & 44 & 11.21 & 0.10 & 1831.97 & 3.05 & 42.59 & \multirow[t]{2}{*}{0.2955} \\
\hline & male & 35 & 19.17 & 0.05 & 329.69 & 7.34 & 42.66 & \\
\hline \multirow[t]{2}{*}{ Family history } & negative & 69 & 16.83 & 0.10 & 1831.97 & 9.04 & 83.99 & \multirow[t]{2}{*}{0.9003} \\
\hline & positive & 10 & 17.87 & 0.38 & 149.63 & 4.07 & 30.21 & \\
\hline \multirow[t]{2}{*}{ Tumour location } & rectum & 30 & 13.29 & 0.16 & 1832.97 & 5.22 & 40.78 & \multirow[t]{2}{*}{0.9672} \\
\hline & colon & 48 & 16.70 & 0.05 & 1699.60 & 2.87 & 48.53 & \\
\hline \multirow[t]{2}{*}{ Histological type } & tubular & 69 & 16.83 & 0.05 & 1831.97 & 4.01 & 44.40 & \multirow[t]{2}{*}{0.5905} \\
\hline & mucinous & 10 & 11.35 & 2.73 & 105.44 & 7.68 & 19.17 & \\
\hline \multirow[t]{2}{*}{ Histological grade } & G1 or G2 & 57 & 16.83 & 0.10 & 1831.97 & 5.63 & 55.32 & \multirow[t]{2}{*}{0.2281} \\
\hline & G3 & 21 & 12.66 & 0.05 & 1699.60 & 2.81 & 25.49 & \\
\hline \multirow{2}{*}{$\begin{array}{l}\text { Invasion of the } \\
\text { intestinal wall }\end{array}$} & $\mathrm{T} 1$ or $\mathrm{T} 2$ & 21 & 16.58 & 0.10 & 1831.97 & 6.81 & 35.99 & \multirow[t]{2}{*}{0.9823} \\
\hline & T3 or T4 & 58 & 16.03 & 0.05 & 1699.60 & 4.01 & 44.40 & \\
\hline \multirow[t]{2}{*}{ Node involvement } & NO & 41 & 16.58 & 0.10 & 1831.97 & 6.81 & 42.66 & \multirow[t]{2}{*}{0.7095} \\
\hline & $\mathrm{pN} 1$ or $\mathrm{pN} 2$ & 34 & 17.04 & 0.05 & 1699.60 & 4.01 & 44.40 & \\
\hline \multirow[t]{2}{*}{ Distant metastasis } & MO & 61 & 16.83 & 0.05 & 1831.97 & 5.63 & 42.66 & \multirow[t]{2}{*}{0.2848} \\
\hline & M1 & 18 & 8.06 & 0.16 & 1699.60 & 2.16 & 39.57 & \\
\hline \multirow[t]{2}{*}{ pTNM stage } & | or || & 40 & 15.90 & 0.10 & 1831.97 & 6.22 & 39.32 & \multirow[t]{2}{*}{0.7611} \\
\hline & III or IV & 39 & 16.83 & 0.05 & 1699.60 & 2.81 & 44.40 & \\
\hline \multirow{2}{*}{$\begin{array}{l}\text { Lymphocytic } \\
\text { infiltration }\end{array}$} & absent & 43 & 9.47 & 0.16 & 1831.97 & 3.17 & 55.32 & \multirow[t]{2}{*}{0.4245} \\
\hline & present & 35 & 18.14 & 0.05 & 1699.60 & 5.04 & 42.44 & \\
\hline \multirow[t]{2}{*}{ Vessel invasion } & absent & 28 & 26.69 & 0.55 & 1831.97 & 9.00 & 60.59 & \multirow[t]{2}{*}{0.0697} \\
\hline & present & 51 & 12.66 & 0.05 & 1699.60 & 2.94 & 40.78 & \\
\hline
\end{tabular}




\section{cDNA synthesis}

RT-PCR reaction was carried out using Enhanced Avian HS RT-PCR Kit, Sigma, according to the manufacturer's protocol. The CDNA was used immediately or stored at $-20^{\circ} \mathrm{C}$. Presence of cDNA in each sample was checked by PCR amplification of $\beta$-actin. Only samples showing the PCR product of this housekeeping gene were included in further tests.

\section{Real-time PCR}

The amount of FJ 194940.1 transcript containing exon V was analysed by means of real-time PCR.

Amplification reactions were performed using Rotor-Gene 6000 (Corbet) and SYBR Green Jump Start Tag ReadyMix ${ }^{T M}$ (Sigma) according to the manufacturer's instructions.

The primer set CTCTCTTGCTGAAATGCTGG (forward) and GGCCCAGGCTTTAAACTATA (reverse) and reaction conditions used in the assay were described earlier [14]. The $25 \mu \mathrm{l}$ reactions consisted of $12.5 \mu$ of JumpStart Taq ReadyMix, $0.5 \mu \mathrm{l}$ of forward primer (final concentration $0.28 \mu \mathrm{l}$ ), $0.5 \mu \mathrm{l}$ of reverse primer (final concentration $0.28 \mu \mathrm{l}$ ), $1.5 \mu \mathrm{l}$ of magnesium chloride (final concentration $3 \mu \mathrm{l}$ ), and $2.5 \mu \mathrm{l}$ of temple cDNA or sterile water. The thermal cycling conditions were 7 minutes at $95^{\circ} \mathrm{C}$, followed by 40 cycles of 60 seconds at $97^{\circ} \mathrm{C}$, 60 seconds at $60^{\circ} \mathrm{C}$, and 60 seconds at $72^{\circ} \mathrm{C}$. Experiments were performed in duplicate to ensure reproducibility of the technique. At the end of each reaction, the threshold was manually set at the level reflecting the best kinetic PCR parameters, the same for all analysed samples. Ct was determined and melting curves were acquired and analysed.

As a reference, the expression of the $b$-actin gene was quantified for each sample using the 5'-GTGGGGCGCCCCAGGCACCA-3' (forward), 5'-CTCCTTAATGTCACGCACGATTTC-3' (reverse) primer set. The reactions for FJ 194940.1 exon $V$ and $\beta$-actin were carried out in separate tubes. The $2^{-\Delta \Delta}$ method invented by Livak and Schmittgen [20] was used to calculate relative changes in gene expression determined from real-time quantitative PCR experiments. Real-time PCR assay has a $100 \%$ amplification efficiency for both genes and was therefore used in the $2(\Delta \Delta C(T))$ method.

\section{Statistical analysis}

STATISTICA 9.1 (StatSoft, Inc., 2010) was used for statistical analyses. The collected quantitative data were tested to check for conformity with a normal distribution on the basis of the Shapiro-Wilk test. Due to a lack of conformity in distributions with normal distribution in every subgroup of patients compared, the statistical analysis of the obtained results employed the nonparametric MannWhitney U test.

Dependences between clinicopathological characteristics, FJ 194940.1 exon V expression levels and overall survival in the entire population of 79 patients were estimated using the Kaplan-Meier estimator (univariate analysis). Overall survival was determined as the interval between surgery and death. Median overall survival time was 65 months (minimum 1 month, maximum 110 months). The log-rank test was used to test for differences in time-to-death distribution.

A Cox proportional hazard regression model (multivariate analysis) was created to identify the independent prognostic factors. A p-value $<0.05$ was assumed as significant in all conducted tests.

\section{Results}

Expression analysis was successful in 87 out of 102 cases of colorectal carcinomas taken for analysis. In 15 of the examined samples, no PCR product was obtained for the housekeeping gene, despite RNA being detected in those cases by spectrophotometric analysis. A possible explanation for this is polymerase chain reaction inhibition, for which there are three likely mechanisms:

- direct interaction between inhibitors and polymerase;

- interaction of the inhibitor with the DNA; or

- interaction with the polymerase during primer extension [21].

It is also possible that the PCR is inhibited by reverse transcriptase [22]. Subsequently, we rejected eight cases as being outliers and extremes.

The analysed population consisted of 44 women and 35 men. Most cases had a negative family history. No statistically significant correlation was observed between exon $\checkmark$ expression level and gender or family history $(p=0.2955$, $p=0.9003$, respectively).

The majority of the investigated tumours were located in the colon. There was no significant correlation between exon $\vee$ expression level and tumour location $(p=0.9672)$.

Previously, all examined cases had been histologically classified as tubular or mucinous type. Sixty-nine cases represent tubular type. There was no significant correlation between exon $\mathrm{V}$ expression level and histological type of tumour $(p=0.5905)$.

The exon $\vee$ expression level was not significantly related to the grade of histological malignancy of the cancer $(p=0.2281)$.

FJ 194940.1 exon V expression level was compared with several clinicopathological parameters such as depth of tumour invasion $(\mathrm{T})$, presence of lymph node $(\mathrm{N})$ and distant metastases (M), or pTNM stage. There was no significant correlation between the expression level and the comparison parameters ( $p=0.9823,0.7095,0.2848,0.7611$, respectively).

No statistically significant correlation has been found between the exon $\vee$ expression level and the presence of lymphocytes in tumour tissue ( $p=0.4245)$. Furthermore, there was no statistically significant correlation between the presence of vessel invasion and the exon $V$ expression level despite a visible tendency towards a lower expression level in a subgroup of cases with vessel invasion presence $(p=0.0697)$.

All of the findings described above are summarised in Table 1.

\section{Exon $\vee$ expression level and survival time}

To carry out a survival analysis, the entire group was divided into two subgroups based on a median value of the exon $V$ expression level in the entire investigated group. The subgroup described as "low" comprised cases having an expression level lower than the median. The subgroup described as "high" comprised cases showing an expression level equal to or higher than the median. There was a sta- 


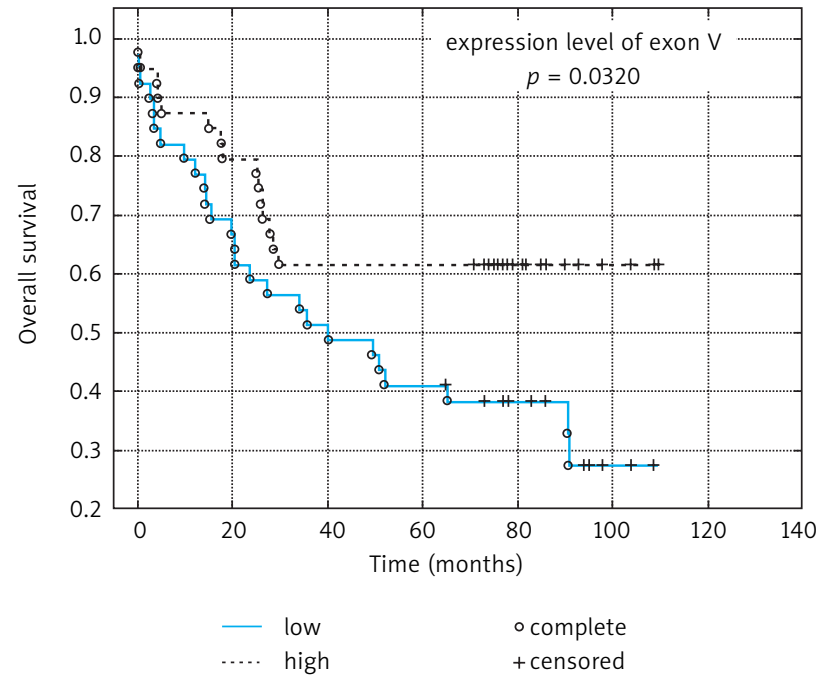

Fig. 1. Overall survival probability in the patient groups with relatively high and relatively low exon $V$ expression levels

tistically significant difference in survival time probability when comparing the two subgroups ( $p=0.0315)$. Patients with a high exon $V$ expression level show a longer survival time than patients with a low exon $V$ expression level (Fig. 1).

The impact of clinicopathological features on survival time was also analysed. Among these, histological grade, invasion

Table 2. Overall survival analysis according to clinicopathological features and exon $\vee$ expression level (univariate analysis)

\begin{tabular}{|c|c|c|c|}
\hline Feature & & $\begin{array}{c}\text { Number } \\
\text { of deaths (\%) }\end{array}$ & $\begin{array}{c}p \text { value } \\
\text { (log-rank test) }\end{array}$ \\
\hline Gender & $\begin{array}{l}\text { female } \\
\text { male }\end{array}$ & $\begin{array}{l}22(50.0) \\
19(55.9)\end{array}$ & 0.3137 \\
\hline Family history & $\begin{array}{l}\text { negative } \\
\text { positive }\end{array}$ & $\begin{array}{l}37(54.4) \\
4(40.0)\end{array}$ & 0.3924 \\
\hline $\begin{array}{l}\text { Tumour } \\
\text { localization }\end{array}$ & $\begin{array}{l}\text { rectum } \\
\text { colon }\end{array}$ & $\begin{array}{l}17(56.7) \\
24(51.1)\end{array}$ & 0.9710 \\
\hline Histological type & $\begin{array}{l}\text { tubular } \\
\text { mucinous }\end{array}$ & $\begin{array}{c}36(52.9) \\
5(50.0)\end{array}$ & 0.9789 \\
\hline Histological grade & $\begin{array}{l}\text { G1 or G2 } \\
\text { G3 }\end{array}$ & $\begin{array}{l}26(46.4) \\
14(66.7)\end{array}$ & 0.0673 \\
\hline $\begin{array}{l}\text { Invasion of the } \\
\text { intestinal wall }\end{array}$ & $\begin{array}{l}\text { T1 or T2 } \\
\text { T3 or T4 }\end{array}$ & $\begin{array}{c}8(38.1) \\
33(57.9)\end{array}$ & 0.0562 \\
\hline $\begin{array}{l}\text { Node } \\
\text { involvement }\end{array}$ & $\begin{array}{l}\text { NO } \\
\text { N1 or N2 }\end{array}$ & $\begin{array}{l}15(36.6) \\
23(69.7)\end{array}$ & 0.0008 \\
\hline $\begin{array}{l}\text { Distant } \\
\text { metastasis }\end{array}$ & $\begin{array}{l}\text { MO } \\
\text { M1 }\end{array}$ & $\begin{array}{l}24(40.0) \\
17(94.4)\end{array}$ & 0.0000 \\
\hline pTNM stage & $\begin{array}{l}\text { I or II } \\
\text { III or IV }\end{array}$ & $\begin{array}{l}15(37.5) \\
26(68.4)\end{array}$ & 0.0012 \\
\hline $\begin{array}{l}\text { Lymphocytic } \\
\text { infiltration }\end{array}$ & $\begin{array}{l}\text { absent } \\
\text { present }\end{array}$ & $\begin{array}{l}25(58.1) \\
15(44.1)\end{array}$ & 0.2299 \\
\hline Vessel invasion & $\begin{array}{l}\text { absent } \\
\text { present }\end{array}$ & $\begin{array}{l}11(39.3) \\
30(60.0)\end{array}$ & 0.0582 \\
\hline $\begin{array}{l}\text { Exon } V \text { expression } \\
\text { level }\end{array}$ & $\begin{array}{l}\text { high } \\
\text { low }\end{array}$ & $\begin{array}{l}14(37.8) \\
26(66.7)\end{array}$ & 0.0315 \\
\hline
\end{tabular}

of the intestinal wall, node involvement, distant metastasis, pTNM stage and venous invasion were each significantly related to survival time (univariate analysis, Table 2). Absence of lymph node involvement (N0, $p=0.0008$ ), absence of distant metastasis (MO, $p=0.0000)$, and lower pTNM stage (pTNM I pTNM II, $p=0.0012$ ) were significantly associated with a longer survival time. Moreover, trends were observed toward a longer survival time in the subgroup of cases of lower malignancy (G1 or G2 stage, $p=0.0673$ ) and lower depth of tumour invasion (T1, T2 $p=0.0562)$. Likewise, absence of vessel invasion was associated with higher overall survival probability $(p=0.0582)$. All of the observed dependences are presented in Table 2.

Variables with a $p$ value of less than 0.1 in univariate analysis were chosen to create a Cox regression model. As histological grade, invasion of the intestinal wall, node involvement, distant metastasis, and vessel invasion showed significant correlation with PTNM stage (Table 3), only pTNM stage and exon $\vee$ expression level were employed to generate the model.

\section{Discussion}

The main aim of the presented research was to assess any prognostic value of the FJ 194940.1 exon V expression level in colon cancer. To achieve the goal, the expression level assessed by real-time PCR was compared with established prognostic factors and survival time of patients with colorectal cancer.

The analysis conducted shows that exon $\vee$ expression level is not related significantly with any clinicopathological features in this series of CRC. However, there was a visible tendency to a higher expression level of this exon in cases where tumours do not infiltrate vessels. Furthermore, high exon V expression level was associated with longer survival times. The statistical results obtained indicate that high expression levels of exon $V$ correspond to a risk of death more than two times lower in comparison to cases with a low exon $V$ expression level and, moreover, that the expression level influences the overall survival time independently of any established prognostic factors.

Qualitative expression analysis of the exon V FJ 194940.1 gene transcript has not shown any correlation with clinicopathological features, or any association with survival time [13]. Using real-time PCR, exon $\vee$ relative expression level in the examined population was shown to be highly diverse, ranging from 0.02 to 18000.36 . In normal human tissue,

Table 3. Correlation between TNM stage and other clinicopathological features and exon $\mathrm{V}$ expression level

\begin{tabular}{|lcc|}
\hline Features & $\begin{array}{c}\text { Correlation } \\
\text { coefficient }\end{array}$ & $p$ value \\
\hline Histological grade (G1 or G2 vs. G3) & 0.241 & 0.041 \\
\hline Invasion of the intestinal wall & 0.488 & 0.000 \\
\hline Node involvement & 0.972 & 0.000 \\
\hline Distant metastasis & 0.534 & 0.000 \\
\hline Vessel invasion & 0.367 & 0.002 \\
\hline Exon V expression level & 0.028 & 0.816 \\
\hline
\end{tabular}


FJ 194940.1 gene is expressed in the kidney [14]. Unpublished data also indicate that in physiological conditions the FJ 194940.1 gene undergoes alternative splicing. Exon $\mathrm{V}$ is an invariable element of all detected variants of FJ 194940.1 in colon cancer. In accordance with the above, it is possible that during cancerogenesis the balance between splice variants of this gene is shifted and some isoforms of this gene are more specific for colon cancer. Consequently, quantitative investigation into the expression of separate elements of the FJ 194940.1 transcript could be more useful for colon cancer prognosis.

There is a link between expression of all elements of the part B FJ 194940.1 transcript and low-grade colon cancer [13]. The study presented here shows links between high exon $V$ level expression and lack of vessel infiltration and longer survival time. Exon $\mathrm{V}$ is an element of the part B FJ 194940.1 transcript. Consequently, the data may suggest that some part of the FJ 194940.1 gene could play a protective role against the spread of cancer cells and metastasis formation. The exact mechanism through which the gene could exert its effect on CRC progression remains unknown. Some elements of FJ 194940.1 gene expression are associated with better prognosis for patients with colorectal cancer in the analysed series.

The conclusions drawn above stand in contradiction to earlier findings obtained in colon cancer cases [16, 18]. Balcerczak M. et al. [18] suggested that expression of a fragment of the FJ 194940.1 gene transcript in colon cancer is engaged in the process of metastasis formation and could be correlated with worse prognosis for the patient. Expression of fragments of the FJ 194940.1 gene transcript was associated with more advanced tumours, with lymph node metastases and with distant metastases. Quantitative analysis has confirmed these observations. It has shown that the expression level of the FJ 194940.1 gene transcript fragment was higher in cancer with metastases to lymph nodes and distant metastases. Higher levels were observed in more advanced cases, classified as III and IV according to the pTNM classification [16].

The discrepancies described might be explained by the difference in the examined fragment of the FJ 194940.1 transcript. The Bartczak et al. [13] studies took separate exons of the FJ 194940.1 gene into consideration, whereas Balcerczak M. et al. [18] and Balcerczak E. et al. [16] analysed the fragment of its transcript that consists of exon $V$ and part of exon IV. Also, alternative pre-mRNA splicing gives the opportunity to generate multiple transcripts from a single m-RNA precursor, so it is possible to develop two isoform encoding proteins with antagonistic functions. An interesting example of cancer-related regulation by alternative splicing is the $B C L-X$ gene. This gene has two splice variants: long antiapoptotic and short proapoptotic [23]. This is caused by the dephosphorylation of SR proteins, a family of protein factors that regulate alternative splicing (known as trans-acting regulatory factors). Modifications of those proteins by dephosphorylation induce changes in the production of particular isoforms - in this situation, increasing the level of proapoptotic splice variant with a simultaneous loss in the antiapoptotic form [23, 24].
FJ 194940.1 gene expression correlates with cancer progression independently of the analysed clinicopathological parameters.

This study is supported by grant 502-03/3-015-02/502-34014-503/3-015-02/503-06-300 from the Medical University of Łódź, Poland.

\section{References}

1. Arnold CN, Goel A, Blum HE, Boland CR. Molecular pathogenesis of colorectal cancer: implications for molecular diagnosis. Cancer 2005; 104: 2035-47.

2. Goel A, Arnold CN, Niedzwiecki D, et al. Characterization of sporadic colon cancer by patterns of genomic instability. Cancer Res 2003; 63: 1608-14.

3. Gardina PJ, Clark TA, Shimada B, et al. Alternative splicing and differential gene expression in colon cancer detected by a whole genome exon array. BMC Genomics 2006; 7: 325.

4. Venables JP. Aberrant and alternative splicing in cancer. Cancer Res 2004; 64: 7647-54.

5. Brinkman BM. Splice variants as cancer biomarkers. Clin Biochem 2004; 37: 584-94.

6. Finn L, Dougherty G, Finley G, Meisler A, Becich M, Cooper DL Alternative splicing of CD44 pre-mRNA in human colorectal tumors. Biochem Biophys Res Commun 1994, 200: 1015-22.

7. Goodison S, Urquidi V, Tarin D. CD44 cell adhesion molecules. Mol Pathol 1999; 52: 189-96.

8. Sternberg LR, Byrd JC, Hansson GC, Liu KF, Bresalier RS. Alternative splicing of the human MUC2 gene. Arch Biochem Biophys 2004; 421: 21-33.

9. Patten LC, Belaguli NS, Baek MJ, Fagan SP, Awad SS, Berger DH. Serum response factor is alternatively spliced in human colon cancer. J Surg Res 2004, 121: 92-100.

10. Huerta S, Srivatsan ES, Venkatesan N, Peters J, Moatamed F, Renner S, Livingston EH. Alternative mRNA splicing in colon cancer causes loss of expression of neural cell adhesion molecule. Surgery 2001; 130: 834-3.

11. Genuardi M, Viel A, Bonora D, et al. Characterization of MLH1 and $\mathrm{MSH} 2$ alternative splicing and its relevance to molecular testing of colorectal cancer susceptibility. Hum Genet 1998, 102:15-20.

12. Pospisil H, Herrmann A, Butherus K, Pirson S, Reich JG, Kemmner W. Verification of predicted alternatively spliced Wnt genes reveals two new splice variants (CTNNB1 and LRP5) and altered Axin-1 expression during tumour progression. BMC Genomics 2006; 7: 148.

13. Bartczak-Tomczyk M, Sałagacka A, Mirowski M, Balcerczak E. Investigation of FJ 194940.1 gene alternative splicing in colon cancer and its association with clinicopathological parameters. Exp Ther Med 2012; 3: 237-42.

14. Balcerczak E, Malewski T, Bartczak M, Mirowski M. Alternation of FJ 194940.1 transcript expression after provirus integration in human neoplasm. Int J Integrat Biol. 2011; 11: 58-63.

15. Balcerczak E, Bartkowiak J, Błoński JZ, Robak T, Mirowski M. Expression of gene encoding P65 oncofetal protein in acute and chronic leukemias. Neoplasma 2002; 49: 295-9.

16. Balcerczak E, Balcerczak M, Mirowski M. Quantitative analysis of the $\mathrm{P} 65$ gene expression in patients with coloroctal cancer. Int J Biomed Sci 2007; 3: 287-291.

17. Czyz W, Balcerczak E, Rudowicz M, Niewiadomska H, Pasieka Z, Kuzdak K, Mirowski M. Expression of C-ERBB2 and P65 genes and their protein products in follicular neoplasms of thyroid gland. Folia Histochem Cytobiol 2003; 41: 91-5.

18. Balcerczak M, Balcerczak E, Pasz-Walczak G, Kordek R, Mirowski M. Expression of the $\mathrm{p} 65$ gene in patients with colorectal cancer: comparison with some histological typing, grading and clinical staging. Eur J Surg Oncol 2004; 30: 266-70. 
19. Chomczynski P, Sacchi N. Single-step method of RNA isolation by acid guanidinium thiocyanate-phenol-chloroform extraction. Anal Biochem 1987; 162: 156-9.

20. Livak KJ, Schmittgen TD. Analysis of relative gene expression data using real-time quantitative PCR and the 2(-Delta Delta C(T)) Method. Methods 2001; 25: 402-8.

21. Opel KL, Chung D, McCord BR. A study of PCR inhibition mechanisms using real time PCR. J Forensic Sci 2010; 55: 25-33.

22. Chandler DP, Wagnon CA, Bolton H Jr. Reverse transcriptase (RT) inhibition of PCR at low concentrations of template and its implications for quantitative RT-PCR. Appl Environ Microbiol 1998; 64: 669-77.

23. Pajares MJ, Ezponda T, Catena R, Calvo A, Pio R, Montuenga LM. Alternative splicing: an emerging topic in molecular and clinical oncology. Lancet Oncol 2007; 8: 349-57.

24. Chalfant CE, Rathman K, Pinkerman RL, Wood RE, Obeid LM, Ogretmen $B$, Hannun YA. De novo ceramide regulates the alternative splic ing of caspase 9 and Bcl-x in A549 lung adenocarcinoma cells. Dependence on protein phosphatase-1. J Biol Chem 2002; 277: 12587-95.

\section{Address for correspondence}

\section{Ewa Balcerczak}

Muszyńskiego 1

90-151 Lodz, Poland

tel./fax +48426779130

e-mail: ewa.balcerczak@umed.lodz.pl

Submitted: 24.042012

Accepted: $\quad$ 14.11.2012 